\title{
Correction to: How closely aligned are China and Russia? Measuring strategic cooperation in IR
}

\author{
Alexander Korolev ${ }^{1}$ (D)
}

(c) Springer Nature Limited 2021

\section{Correction to: International Politics (2020) 57:760-789 https://doi.org/10.1057/s41311-019-00178-8}

The article "How closely aligned are China and Russia? Measuring strategic cooperation in IR", written by Alexander Korolev was originally published electronically on the publisher's internet portal (currently SpringerLink) on May 09, 2019 without open access. The copyright of the article changed to (C) The Author (s) and this article is licensed under a Creative Commons Attribution 4.0 International License, which permits use, sharing, adaptation, distribution and reproduction in any medium or format, as long as you give appropriate credit to the original author(s) and the source, provide a link to the Creative Commons licence, and indicate if changes were made. The images or other third party material in this article are included in the article's Creative Commons licence, unless indicated otherwise in a credit line to the material. If material is not included in the article's Creative Commons licence and your intended use is not permitted by statutory regulation or exceeds the permitted use, you will need to obtain permission directly from the copyright holder. To view a copy of this licence, visit http://creativecommons.org/licenses/by/4.0/.

The original article has been updated.

Publisher's Note Springer Nature remains neutral with regard to jurisdictional claims in published maps and institutional affiliations.

The original article can be found online at https://doi.org/10.1057/s41311-019-00178-8.

Alexander Korolev

a.korolev@unsw.edu.au

1 School of Social Sciences, University of New South Wales, Sydney, NSW 2052, Australia

Published online: 11 October 2021 